\title{
Surrealist Cosmology: André Breton and Astrology
}

\section{Nicholas Campion}

Abstract. The influence of significant strands of late-nineteenth and earlytwentieth century esoteric thought on the surrealist movement has often been noted, though has been little studied. Part 1 of this paper summarises current opinions on the esoteric interests of the surrealists in general and André Breton in particular. Part 2 includes an interview with Breton on astrology conducted by Jean Carteret and Roger Knare in 1954 and published in the French astrology journal L'Astrologue in 1968, reproduced by permission of André Barbault

\section{Part 1}

André Breton (1896-1966), poet and critic, was a pioneer in the earlytwentieth century anti-rationalist movements in art. He was one of the founders and leaders of the surrealist movement and a leading exponent of dadaism. He expressed his opinions in Littérature, the leading surrealist periodical, which he helped found and edited for many years, and also drafted the three Surrealist manifestos of 1924, 1930 and 1942. Breton had studied medicine and worked in psychiatric wards in World War 1, so it was natural that he should also study Freud: he was deeply influenced by the belief that much of what is important in the human psyche happens at an unconscious level, hidden from normal rational perceptions. Surrealism's explicit debt to Freud as well as to Marx and Hegel, together with its claim to have finally put the 'romantic principle' onto a 'scientific basis', was summarised in 1937 by Herbert Read, one of Breton's collaborators.

However, while surrealism's debt to psychoanalysis is widely acknowledged, its debt to other aspects of the Western esoteric tradition, particularly theosophy, has often been hinted at but rarely studied. In the essentially conservative world of art-criticism such interests are often considered odd. For example, writing on the Futurists, Umbro Appollonio, commented that 'before 1910 (they) were still bound up with Symbolism and even metaphysics and occultism...' (my emphasis). ${ }^{2}$ It is, though, widely assumed that the automatic writing of H.P. Blavatsky,

Nicholas Campion, 'Surrealist Cosmology: André Breton and Astrology', Culture and Cosmos, Vol. 6 no 2, autumn/winter 2002, pp. 45-56.

www.CultureAndlCsomos.org 
who founded the Theosophical Society in 1875 , was also influential in encouraging the surrealists' 'automatic painting' - the belief that creative truths could be expressed if one could surrender oneself to the unconscious or to a transcendent reality, free from the restrictions of rationality. (Two of the leading surrealists who joined the Theosophical Society were Wasilly Kandinsky and Piet Mondrian. ${ }^{3}$ ) Similarly, the interest of other early twentieth-century artists specifically in astrology has been noted but never investigated - with a few exceptions, such as Gustav Holst ${ }^{4}$ and W.B. Yeats. ${ }^{5}$ The following interview with André Breton on his study of astrology was conducted in 1954 at a time when his artistic direction and ideology were shifting.

According to Sarane Alexandrian, one of Breton's close friends, it was in the last ten years of his life that Breton accomplished 'the profound, real occultation of surrealism'. ${ }^{6}$ By 'occultation' he meant what Alexandrian defined as 'its transformation into a secret circle, a closed group, with the task of cultivating the idea of forces of the modern world in an ideal climate, much as the esoteric sciences were practised in the Middle Ages'. ${ }^{7}$ This new exclusivism was a response to the belief that the freedoms for which the surrealists had fought were now a part of mainstream society and that surrealism could therefore maintain its cohesion only by setting up further barriers between it and the mainstream.

In common with other art historians, Alexandrian does not mention Breton's astrology but does discuss his interest in magic, reporting that 'During this period of occultation, the studies which surrealist art pursued began to probe into magic, maybe not in the hope of deriving direct inspiration from it, but at least to use it as a system of reference'. ${ }^{8}$ This transition was apparently a result of Breton's increasing interest in Celtic iconography, which developed after he read Lancelot Lengyel's L'Art gaulois dans des médailles in 1954. Breton was very critical of the politics involved in such art, for example the dispute between proponents of figurative and non-figurative painting, and in 1955 he organised the exhibition 'Pérennité de l'Art gaulois' at the Musée Pédagogique, including ancient Gallic medals together with modern paintings which shared a desire to assert a Gallic identity against the 'Graeco-Roman yoke'. He was aware of the limitations of such a 'law of proximity', but believed that 'the idea of magic was flexible enough to reconcile apparently irreconcilable tendencies in art'. ${ }^{9}$ In 1957 he explored magical themes further in his L'Art magique, an attempt to purify the sources of aesthetic judgment. By applying the epithet 'magic' to art he hoped to 
encourage the construction of a new hierarchy of values and a 'dignification' of the work of art beyond existing intellectual and criteria. $\mathrm{He}$ also hoped to encompass works from traditions of visual work not normally included in the Western canon. Hence his illustrations included Tibetan banners, Tarot symbols and alchemical images, as well as scenes from contemporary cinema. He drew a parallel between 'magic in practice' as it had existed in the past and works which may not be explicitly related to any aspect of magical doctrine or ritual but nevertheless exert a magical power over us. J.H. Matthews made Breton's purpose clear: he wished to replace all that surrealism had torn down with 'the appetite for the marvellous'. ${ }^{10}$ Mathews continues that, for Breton, the marvellous was 'the sole source of eternal communication between men', while, according to André Pieyre de Mandiarges,

in this invasion of reality by the marvellous rises a very vast country in which the witness, skilful enough to observe the phantasmagoric elements without frightening them off by too much attention, will be able to walk with profit. ${ }^{11}$

Further, the surreralists aspired to

a state of perception and experience that will permit them to witness the complete transformation of the world of concrete reality in response to man's desire, alone considered capable of bringing the marvellous within reach. Here the Surrealist effort to act upon reality is expressively voiced. Absurdity, incongruity, distraction, and all other forms of opposition marshalled by Surrealism in its struggle against blind acceptance and static conventions, constitute an attack upon the unyielding façade of a world that will not recognise its own limitations, and which is thus incapable of ensuring the happiness of mankind

Whether the Surrealist talks of making the final leap, or of crossing the bridge, or of penetrating to the other side of the mirror, his ambitions remain the same, as does his confidence that they will be fulfilled only with the help of imagination. Surrealism declares imagination to be possessed of limitless power to give man the opportunity to bend the world to his desire, to modify it according to the demands he feels entitled to make of it. Reflecting upon his dreams, weighing the discoveries he owes to the practice of automatism and to the revelations of chance, responsible to the sense of liberation made possible by prospecting the world of the irrational, 
the Surrealist can draw only one conclusion: the marvellous - which is no more than the projection of the surreal he hopes one day to experience fully - is not that which might have been. It is, in fact, that which may be, and must be. The marvellous is what man can make it, by submission to no authority but that of his own desire. ${ }^{12}$

As Kandinsky wrote of the arts, 'In each manifestation is the seed of a striving towards the abstract, the non-material. Consciously or unconsciously they are obeying Socrates' command - Know thyself'. ${ }^{13}$ Alexandrian argues that the magical art of Breton's later career complemented rather than replaced the revolutionary art of his earlier life. The artist's creative autonomy remains supreme. Breton wrote that 'Magic implies protest, in other words revolt' and, on ancient works which result from magical practices, 'With some few exceptions, their hold over us is not a result of the magic with which they were originally impregnated, but of the beauty which flows from them, even though this beauty may not have been consciously sought, but may have arisen only incidentally'. ${ }^{14}$ According to Alexandrian,

Revolution and Magic are the two values which surrealism used to conceal its unconfessed raison d'être, which was to make a religion out of poetic inspiration. These two values constantly succeeded each other, turn and turn about, like day and night, in surrealist thought, whose contributions are a direct result of the impossibility of reconciling them. Whenever the surrealists settled for one or the other of these two values, they did so in almost identical terms; the works which Breton regarded as magic move in the same direction as those he regarded as revolutionary. ${ }^{15}$

It was in this context that Jean Carteret and Roger Knare conducted their interview on astrology with Breton in April 1954. 
Images from André Breton, L'Art Magique 1957, p. 17.

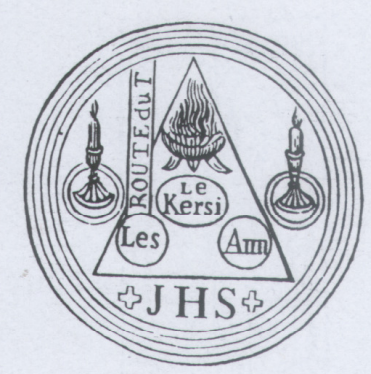

Le triangle des pactes. Le Dragon rouge, Avignon 1522. Coll.

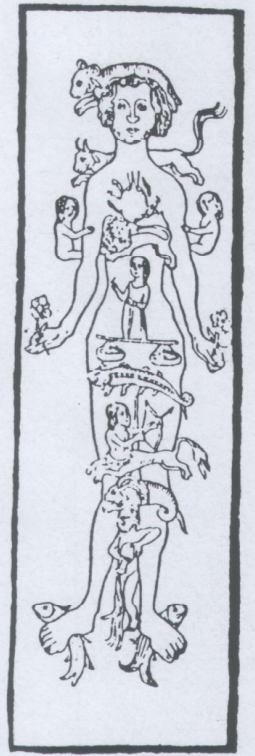

Position des signes du zodiaque dans le corps humăin. Compost et Calendrier des bergers.

Culture and Cosmos Vol. 6 no 2 
50 Surrealist Cosmology: André Breton and Astrology

Images from André Breton, L'Art Magique 1957, p. 21.

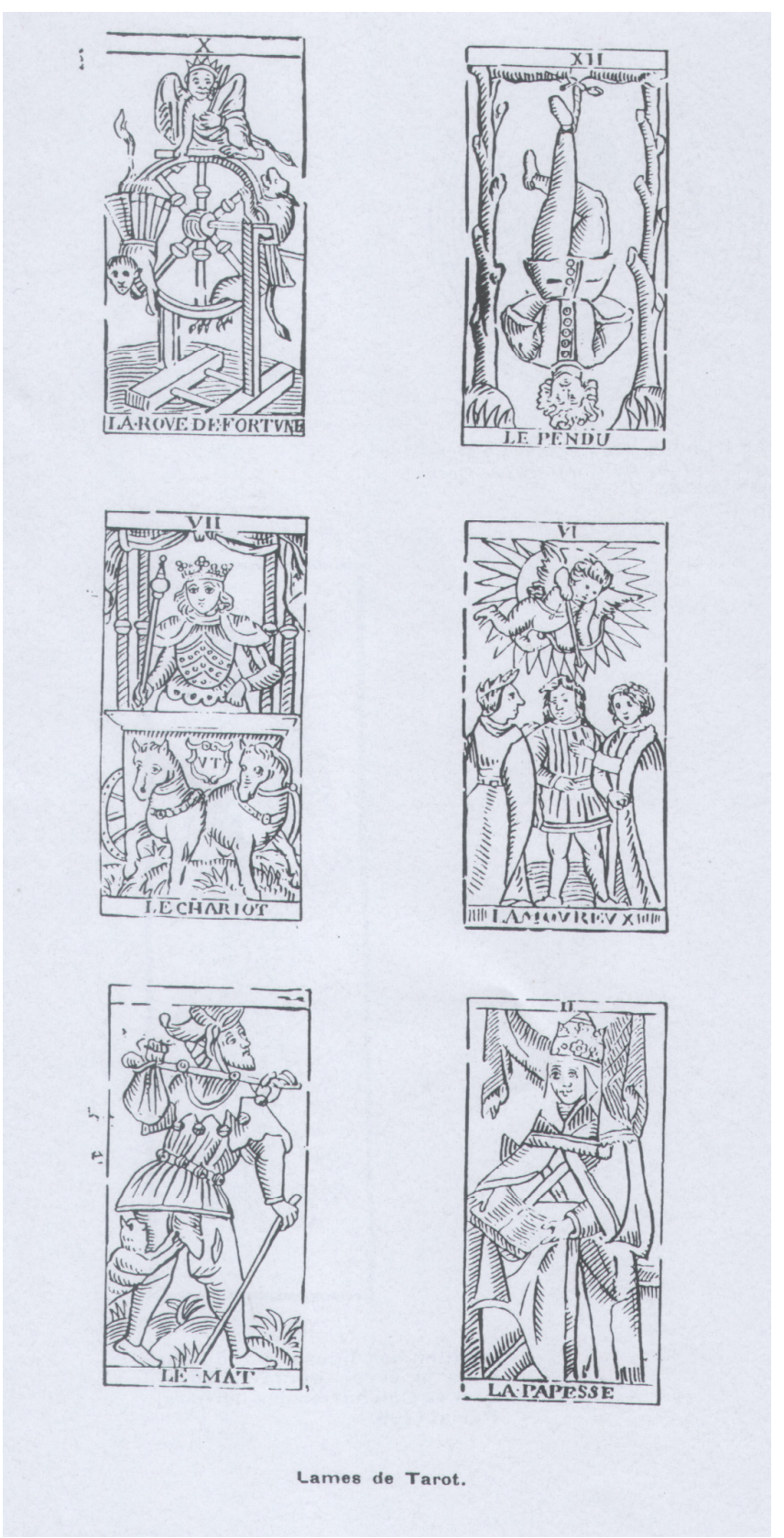

Culture and Cosmos Vol. 6 no 2 
Images from André Breton, L'Art Magique 1957, p. 169.

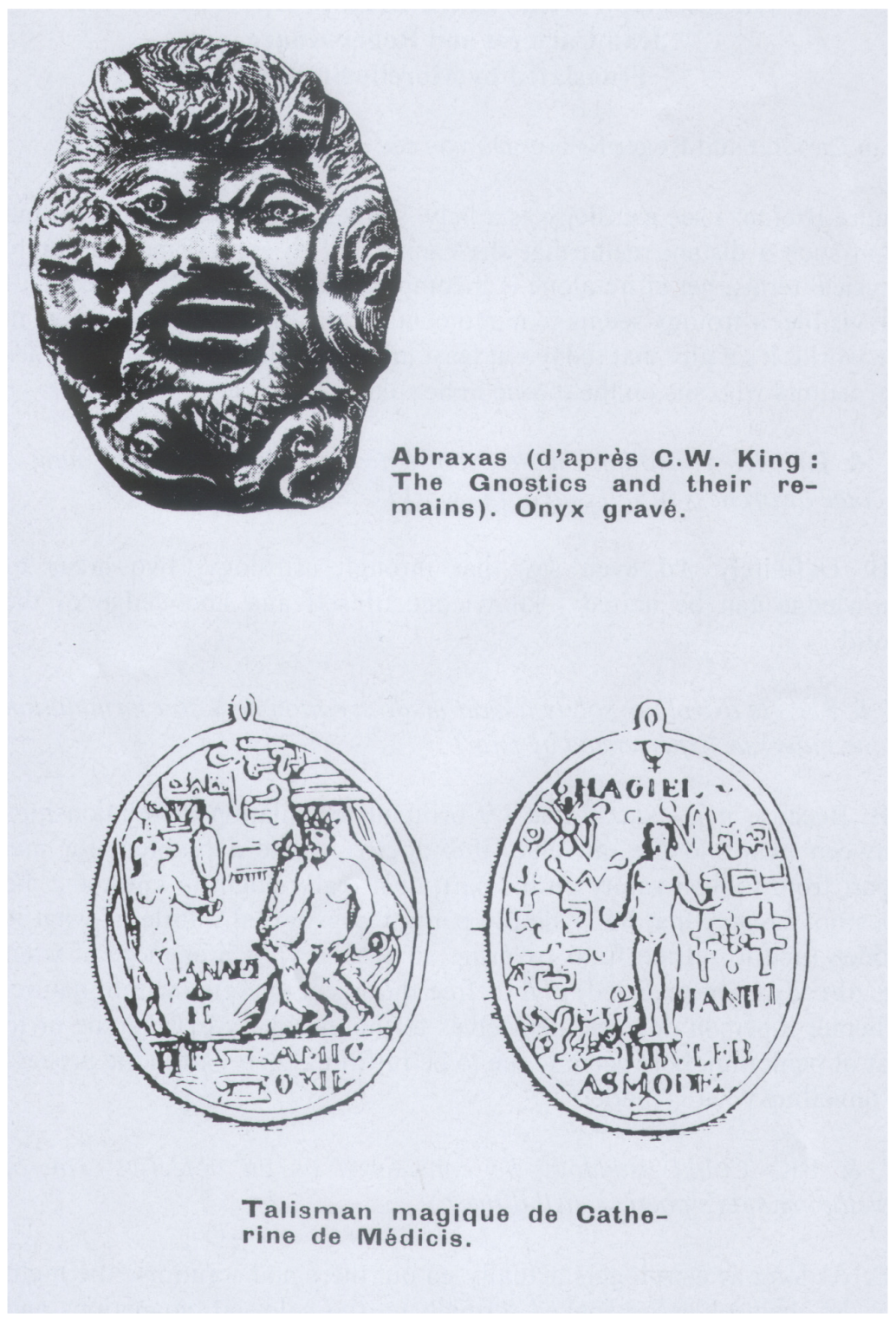

Culture and Cosmos Vol. 6 no 2 


\section{Part 2}

\section{An interview with André Breton, April 1954. Jean Carteret and Roger Knare Translated by Morelle Smith.}

Jean Carteret and Roger Knare: Do you see any value in astrology?

André Breton: I see astrology as a lady, statuesque, utterly beautiful, and from such a distant realm that she cannot fail to enthral me. In purely physical terms, her attire alone is incomparable. But beyond the realm of the visible, astrology seems to me to contain one of the highest secrets in the world. It's a pity that today - at least in the popular understanding - it's a prostitute who sits on the throne in her place. ${ }^{16}$

JC \& RK: Do you think the study of astrology can develop in man a greater awareness of self and of the world?

AB: Definitely. I'd even say that through astrology, two areas of knowledge can be united - knowledge of self and knowledge of the world.

JC \& RK: Is astrology solely a man-made creation or is it a formulation of the universe, experienced by man?

$\mathrm{AB}$ : Because it is exactly that - a brilliant formulation of relationships between man and the universe, this doesn't create a problem for me. Apart from foolish vanity on his part, man really ought to know that he does not 'create', that he is simply permitted to reveal a little of what is hidden (and to refrain from covering up again as much or more of what has already been revealed) and to free the latent energies within nature. Whether a person devotes themselves to the discovery of Neptune or to that of penicillin, both seem to me to be fulfilling their part in the process of unveiling what is hidden.

JC \& RK: Could astrology be considered as an objective way of developing man's poetic sensibilities?

$\mathrm{AB}$ : As long as astrologers actually go out there and scrutinise the night sky, let themselves be soaked through by the celestial emanations and 
then bring this brightness back to the darkness of human existence then yes, all the poetic abilities will play their part. Since the appearance of ephemerides - so practical and - even better, don't you think, within everyone's reach - I think the poetic qualities will undoubtedly play their part.

JC \& RK: What connections did the surrealists have with astrology?

AB: Sporadic unfortunately, and it varied with each individual. Astrology, like poetry, demands not only that you commit yourself to it entirely but also requires specific signs of a predestined nature. For my part, I learnt the basics of astrology around 1927. After that, I was able to benefit a little from Pierre Mabille's extensive knowledge of the subject and he introduced me to Fludd, ${ }^{17}$ which allowed me to go beyond the deadly mediocrity of most of modern texts. The surrealists generally took a lively interest in astrology, seeing it from a poetic perspective, without going very deeply into it.

JC \& RK: If we can talk of astrology as being considered as a lyrical game, would you go as far as describing astrology as the tool of an architecture of universal relationships?

AB: Not being a geometrician, even less so in the ancient sense of the term, I'm not qualified to talk about that. What I've always valued enormously in astrology is not so much the lyrical game to which it lends itself, as the multi-layered logical game which is a necessary part of it and on which it is founded. Quite apart from the very subtle means of evaluation that astrology uses and its predictive abilities, I consider its capacity for stretching and exercising the mind to be second to none. To unravel a destiny, beginning with the planetary placements, their aspects, their signs and houses, depending on the position of the Ascendant and Midheaven - this requires more than enough mental dexterity to silence any attempts at ridicule and, compared with this sophistication, conventional logical reasoning comes out looking like child's play.

JC \& RK: Would you say that astrology could be seen as the golden language of analogy, in the way that counterpoint and harmony are to music? 
AB: I have to be excused to some extent, as I lack the musical vocabulary. I would say though, that astrology is the 'golden language' of analogy in that it has created a vast resource of corresponding references between man and nature. I can think of no other system with as great an aspiration to harmony (in the sense that Fourier used that word).

JC \& RK: If we take the thorny question of quality in astrology, what do you think about the responsibility involved in being an astrologer?

AB: I consider that responsibility to be enormous, and I also think that the 'International Centre of Astrology' should, as a matter of urgency, warn the public against the venal enterprises and the shameful exploitation of people's credulity which are bringing it into disrepute (newspaper horoscopes etc).

JC \& RK: Do you see any common ground between the belief in free will and that of a future that can be predicted?

$\mathrm{AB}$ : This brings us back I think, to the case of Jerome Cardan, ${ }^{18}$ who allowed himself to die of hunger at the age of 75 , so that the prediction of his horoscope would be fulfilled, and the truth of astrology would be vindicated. I don't think anything needs to be added to what Grillot de Givry said about this.

Those on the side of free will claim that the death was accomplished through the means of free will; but their opponents maintain that the fatal event was nonetheless predetermined and that it was written in the book of fate that he was to die of hunger whatever might be the reason for this kind of death.

\section{Acknowledgment}

This interview was originally published in $L^{\prime}$ Astrologue No 4, 1968, pp. 4-6. We are grateful to André Barbault for permission to publish. 


\section{References}

1. Read, Herbert (ed.), Surrealism, London: Faber and Faber 1937, p. 22, see also, pp. 28, 66-7, 76-7, 100-1.

2. Apollonio, Umbro, Futurist Manifestos, London: Thames and Hudson, 1970, p. 15.

3. Hughes, Robert, The Shock of the New: Art and the Century of Change, London: Thames and Hudson 1991, pp. 202, 299. See also Hall. Kathleen, 'Theosophy and the Emergence of Modern Abstract Art', The Quest, May-June 2002, vol. 90 no 3, pp 84-87, 109. For general discussions see Choucha, Nadia, Surrealism and the Occult, Oxford: Mandrake 1991, Waldo-Schwartz, Paul, Art and the Occult, London: Mandala 1977. Also see Düchting, Hajo, Wassily Kandisnky, Cologne: Benedikt Raschen Verlag 1991, p. 58. Düchting argued that Kandinsky's attempts to reveal the spiritual nature of colour was directly influenced by theosophical claims to be able to see auras.

4. Head, Raymond, 'Astrology, Modernism and Holst's "The Planets"', Astrology Quarterly, Vol. 65 no 1, Winter 1994-5, pp. 40-54.

5. Heine, Elizabeth, 'W.B. Yeats: Poet and Astrologer', Culture and Cosmos, Winter/Autumn 1997, Vol. 1 no 2, pp. 60-75.

6. Cited in Alexandrian, Sarane, Surrrealist Art, London: Thames and Hudson 1970, p. 218.

7. Alexandrian, Surrrealist Art, p. 218.

8. Alexandrian, Surrrealist Art, p. 219.

9. Alexandrian, Surrrealist Art, p. 219.

10. Matthews, J.H., An Introduction to Surrealism, University Park, Pennsylvania: The Pennsylvania State University Press 1965, p. 136.

11. Matthews, Surrealism, p. 137.

12. Matthews, Surrealism, p. 150.

13. Kandinsky, Wassily, Concerning the Spiritual in Art, trans. M.T.H. Sadler, New York: Dover Publications 1977 (1st edn., London 1914).

14. Cited in Alexandrian, Surrrealist Art, p. 220.

Culture and Cosmos Vol. 6 no 2 
56 Surrealist Cosmology: André Breton and Astrology

15. Alexandrian, Surrrealist Art, p. 220.

16. This passage was to be the starting point for Michel Gauquelin's Written in the Stars, Wellingborough: Aquarian Press 1988, p. 11. Gauquelin's point was that while astrology thrived in the media, it existed in a scientific void, which is what he set out to remedy with his statistical research. From Gauquelin this passage was cited by Charles Harvey, former President of the Astrological Association in 'Notes', Astrological Journal, March/April 1995, vol. 77 no 2, p. 86. Harvey added 'Such is the vision of astrology that has certainly inspired the founders and leaders of the AA and British astrology for many decades, and such is the shadow with which astrology constantly has to make peace'.

17. Robert Fludd (1574-1637); see Godwin, Joscelyn, Robert Fludd: Hermetic Philosopher and Surveyor of Two Worlds, London: Thames and Hudson 1979.

18. Jerome Cardan (1501-1576); see Grafton, Anthony, Cardano's Cosmos: the Worlds and Works of a Renaissance Astrologer, Cambridge and London: Harvard University Press 1999.

Culture and Cosmos Vol. 6 no 2 